\section{Sejarah \\ Lubuklinggau}

Dari Masa Kolonial Hingga Kemerdekaan

Buku ini merupakan sekumpulan artikel penulisyang gagas ulang sehingga tersusun sebuah buku yang berjudul Sejarah Lubuklinggau: Dari Masa Kolonial Hingga Kemerdekaan. Perjalanan sejarah Kota Lubuklinggau memiliki kisah yang sangat panjang dilihat dari berbagai periodeisasi dan kronologi sejarah, dimulai dari daerah pedalaman (sindang) masa Kesultanan Palembang Darussalam, berlanjut masa Kolonial Hindia Belanda, masa Pendudukan Jepang, masa Kemerdekaan RI dan masa perjuangan revolusi fisik.

Oleh karena itu, buku ini berusaha menyajikan beberapa tulisan sejarah terkait perjalanan sejarah Lubuklinggau meliputi: (1). Lubuklinggau dalam Kurun Waktu 1825-1949, (2). Perubahan Birokrasi Marga Moesi Oeloe di Afdeeling Palembangsche Bovenlanden 1906-1942, (3). Pembangunan Jalur Kereta Api Sumatera Selatan rute Palembang-Lubuklinggau Tahun 19141942, (4). Sejarah Pembentukan Sub Teritorium Sumatera Selatan (SUBKOSS) Tahun 1945-1948, (5). Kolonel Maludin Simbolon pada Agresi Militer Belanda II di Lubuklinggau 1947-1948, (6). Menelusuri Jejak Perjuangan Sub Komandemen Sumatera Selatan (SUBKOSS).

Buku ini mengawali penulisan sejarah lokal tentang kisah dan perjalanan Lubuklinggau pada masa lampau. Dan tidak menuntut kemungkinan akan kajian sejarah yang lebih komprehensif dari para peneliti agar menjadi sejarah yang lebih kompleks.
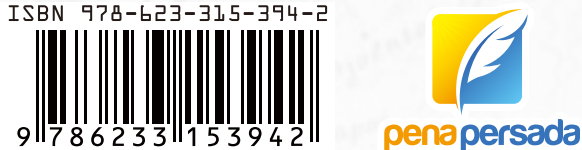

\section{Berlian Susetyo \\ Ravico}

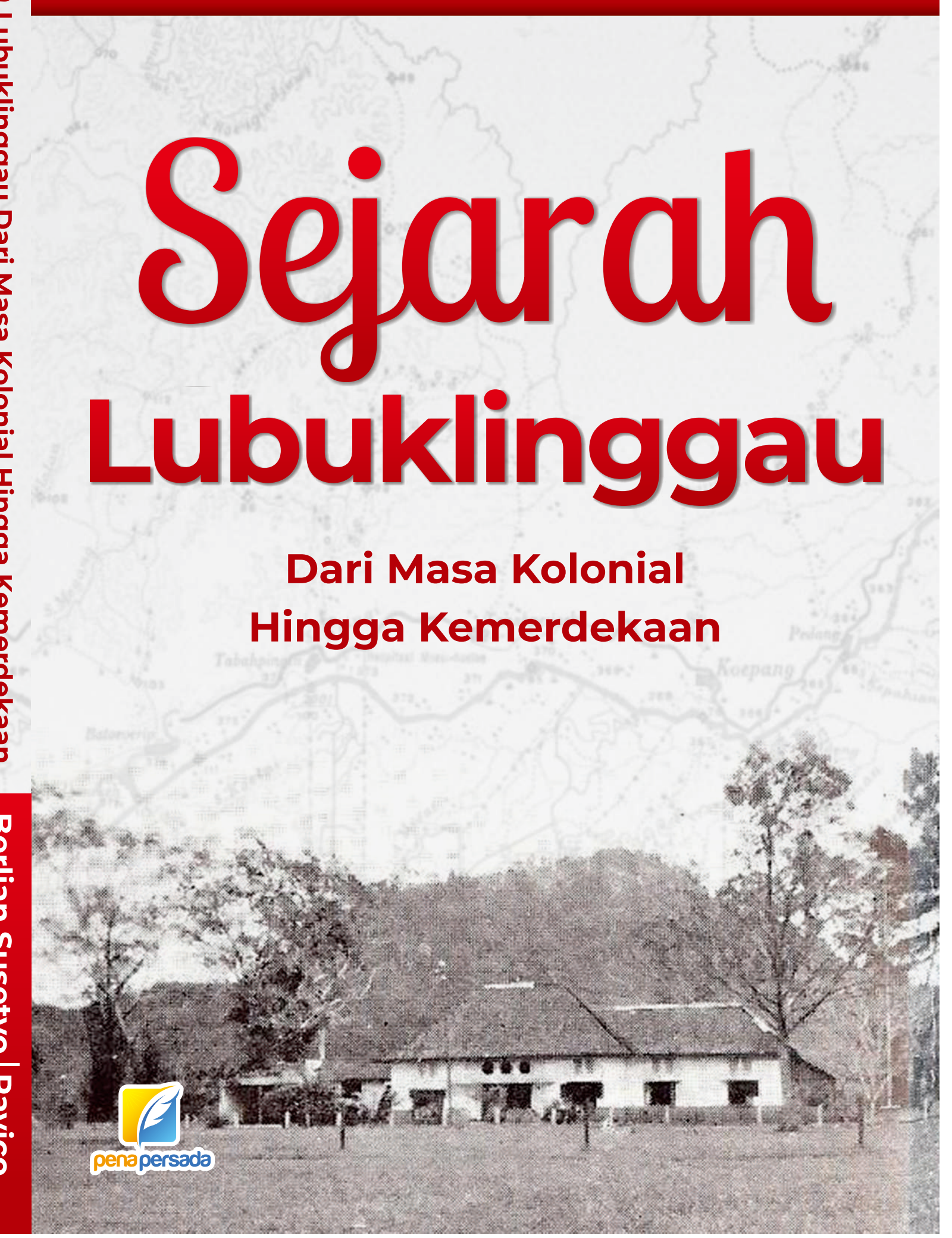




\title{
Sejarah Lubuklinggau : \\ Dari Masa Kolonial Hingga Kemerdekaan
}

\author{
Berlian Susetyo
}

Ravico

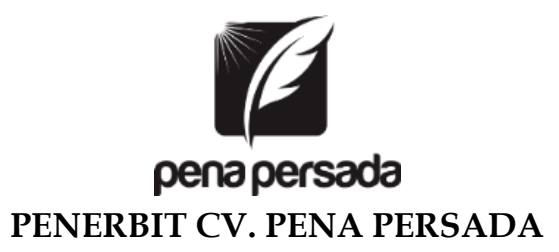




\section{Sejarah Lubuklinggau : \\ Dari Masa Kolonial Hingga Kemerdekaan}

Penulis:

Berlian Susetyo

Ravico

ISBN : 978-623-315-394-2

Design Cover :

Retnani Nur Briliant

Layout :

Eka Safitry

\section{Penerbit CV. Pena Persada}

Redaksi :

Jl. Gerilya No. 292 Purwokerto Selatan, Kab. Banyumas

Jawa Tengah

Email : penerbit.penapersada@gmail.com

Website : penapersada.com Phone : (0281) 7771388

Anggota IKAPI

All right reserved

Cetakan pertama : 2021

Hak Cipta dilindungi oleh undang-undang. Dilarang memperbanyak karya tulis ini dalam bentuk apapun tanpa izin penerbit 


\section{PRAKATA}

Buku “Sejarah Lubuklingau: Dari Masa Kolonial Hingga Kemerdekaan" ini memuat perjalanan panjang mengenai sejarah Lubuklinggau. Buku ini merupakan sekumpulan artikel penulis yang gagas ulang sehingga tersusun menjadi sebuah narasi sejarah. Inti dari seluruh pembahasan ini akan ditarik sebuah proses peristiwa yang kronologis.

Kota ini bermula dari sebuah daerah kecil bernama Batu Kuning di huluan Sungai Musi, bagian wilayah Sindang masa Kesultanan Palembang Darussalam. Kekuasaan kesultanan jauh hingga pedalaman hanya dapat dilalui jalur sungai, dan sungai Kelingi ialah salah satu sungai yang melintasi daerah Batu Kuning ini sehingga perkembangan selanjutnya Lubuklinggau menjadi marga kecil yakni Batu Kuning Kelingi. Jatuhnya pemerintahan Kesultanan Palembang Darussalam ke tangan Belanda tahun 1825 merubah seluruh tatanan pemerintahan. Kebijakan Residentie Palembang untuk daerah uluan mulai dibentuk hingga menggabungkan beberapa marga seperti Batu Kuning Kelingi dengan Batu Kuning Lakitan menjadi marga Sindang Kelingi Ilir dengan menempatkan Loeboeklinggau sebagai kedudukan setelah ada regulasi pemerintah tahun 1859. Masyarakat awal tinggal di sebuah kawasan pinggiran sungai Kelingi yang saat ini dikenal menjadi Situs Purbakala Ulak Lebar.

Eksistensi Lubuklinggau semakin terlihat jelas ketika jalur kereta api sampai di daerah ini untuk menunjang roda perekonomian sepeti Ondernaming Belalau, Perkebunan Kepala Sawit di Air Temam, hingga pada akhirnya memindahkan pemerintahan Onder Afdeeling Moesi Oeloe dari Muara Beliti ke Lubuklinggau Tahun 1934. Kelancaran transportasi kereta api ini menunjang salah satu kebijakan Politik Balas Budi Belanda dengan mendatangkan transmigran Jawa untuk mengurus lahan pertanian. Belanda membentuk daerah koloninya sehingga muncul kolonisasi Tugumulyo, sampai pada pembangunan sarana irigasi Watervang dipergunakan untuk mengaliri areal persawahan bagi warga koloni dan warga lokal Tugumulyo. 
Pada tahun 1942, Jepang menguasai bekas wilayah jajahan Hindia Belanda dan mulai merubah seluruh tatatan sesuai kepentingan militer. Bunshu Musikami Rawas menjadi pemerintahan di Lubuklinggau, dengan Musikami Gun dan Rawas Gun bagian dari pemerintahan. Para pasukan Jepang menjadikan serdadu Belanda menjadi tawanannya yang ditempatkan di bekas perkebunan karet dikenal dengan Kamp Belalau. Hingga tiba masa proklamasi kemerdekaan, praktis pemerintahan Bunshu Musikami Rawas berubah nama menjadi Kabupaten Musi Ulu Rawas. Berlanjut pada perjuangan revolusi fisik kemerdekaan, posisi Lubuklinggau semakin penting setelah pemerintahan Karesidenan Palembang menempatkan Lubuklinggau sebagai ibukota sementara, sedangkan Curup menjadi ibukota Provinsi Sumatera Selatan. Posisi strategis Lubuklinggau ini akibat penghubung dari kawasan Sumatera bagian Selatan, maka militer SUBKOSS (Sub Teritorium Sumatera Selatan) juga menempatkan Lubuklinggau sebagai markas kedudukan. Militer SUBKOSS dipimpin oleh Kolonel Maludin Simbolon dalam kepentingan mempertahankan kedaulatan dari keinginan Belanda yang berniat menghapus kedaulatan Indonesia dalam peristiwa Agresi Militer II Belanda.

Lubuklinggau, Mei 2021

Berlian Susetyo \& Ravico 


\section{DAFTAR ISI}

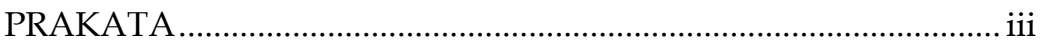

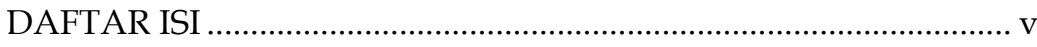

PENDAHULUAN DINAMIKA PENULISAN SEJARAH LOKAL..1
A. Penulisan Sejarah Lokal. .1
B. Tantangan Penulisan Sejarah Lokal .....................................5
C. Dinamika Penulisan Sejarah Lokal Lubuklinggau ..........8
D. Metode Penelitian. 10

BAGIAN I LUBUKLINGGAU DALAM KURUN WAKTU 18251949

A. Lubuklinggau pada Masa Kolonial Belanda Tahun 1825-1942

B. Lubuklinggau Masa Pendudukan Jepang Tahun 19421945

C. Lubuklinggau Masa Kemerdekaan RI Tahun 1945 .......31

D. Lubuklinggau pada Agresi Militer Belanda I Tahun 1947

E. Lubuklinggau pada Agresi Militer Belanda II Tahun 1948

F. PENUTUP

BAGIAN II PERUBAHAN BIROKRASI MARGA MOESI OELOE DI AFDEELING PALEMBANGSCHE BOVENLANDEN 1906-1942

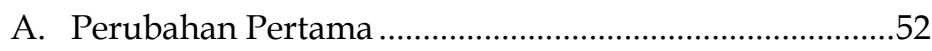

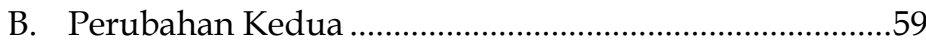

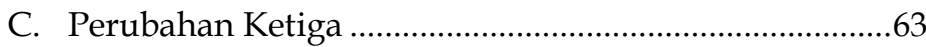

D. Perubahan Keempat..............................................................64

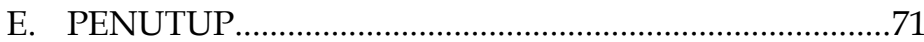


BAGIAN III PEMBANGUNAN JALUR TRANSPORTASI KERETA API RUTE PALEMBANG - LUBUKLINGGAU TAHUN 1914-1942

A. Awal Pembangunan Jalur Kereta Api di Sumatera Selatan......

B. Transportasi Kereta Api sebagai Angkutan Manusia dan Barang

C. PENUTUP 95

BAGIAN IV SEJARAH PEMBENTUKAN SUB TERITORIUM SUMATERA SELATAN (SUBKOSS) TAHUN 1945-1948....97

A. Polemik Pembentukan Komandemen Sumatera ........ 103

B. Sub Komandemen Sumatera Selatan (SUBKOSS) ......112

C. SUBKOSS berubah menjadi Divisi VIII/Garuda ........117

D. Kembali menjadi SUBKOSS akibat Kebijakan RERA 123

E. PENUTUP 131

BAGIAN V KOLONEL MALUDIN SIMBOLON PADA AGRESI MILITER BELANDA II DI LUBUKLINGGAU TAHUN 19471948 133

A. Biografi Kolonel Maludin Simbolon 136

B. Kolonel Maludin Simbolon diangkat menjadi Panglima SUBKOSS.

C. Kebijakan Kolonel Maludin Simbolon dalam menghadapi Agresi Militer Belanda II

D. PENUTUP 156

BAGIAN VI MENELUSURI JEJAK PERJUANGAN SUB KOMANDEMEN SUMATERA SELATAN (SUBKOSS) ....158

A. Sejarah Gedung Museum SUBKOSS 162

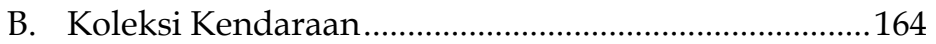

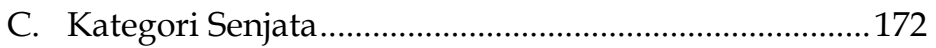

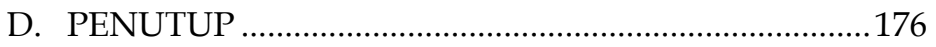




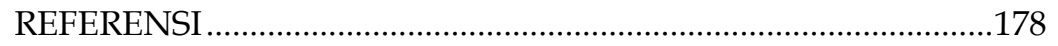

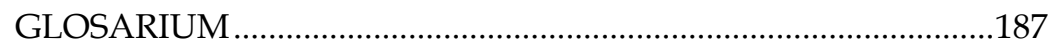

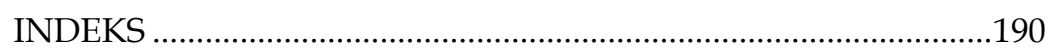

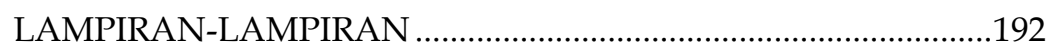

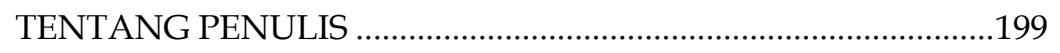


Sejarah Lubuklinggau :

Dari Masa Kolonial Hingga Kemerdekaan 


\section{PENDAHULUAN \\ DINAMIKA PENULISAN SEJARAH \\ LOKAL}

\section{A. Penulisan Sejarah Lokal}

Sejarah lokal bisa dikatakan sebagai suatu bentuk penulisan sejarah dalam lingkup yang terbatas meliputi suatu lokalitas tertentu. Keterbatasan lingkup itu terutama biasanya dikaitkan dengan unsur wilayah (spatial). Istilah sejarah lokal sendiri menurut Taufik Abdullah ${ }^{1}$ merujuk pada pengertian kata lokal, hanyalah 'tempat, ruang'. Jadi 'sejarah lokal' hanyalah berarti sejarah dari suatu 'tempat', suatu 'locality', yang batasannya ditentukan oleh 'perjanjian' yang diajukan penulis sejarah". Batasan geografisnya berupa suatu tempat tinggal suku bangsa, yang kini mungkin telah mencangkup dua-tiga daerah administratif tingkat dua atau tingkat satu (suku bangsa Rejang, umpamanya) dan dapat pula suatu kota, atau malahan suatu desa. Hal tersebut senada dengan Widja² dalam bukunya yang berjudul "sejarah lokal suatu perspektif sejarah" menjelaskan bahwa sejarah lokal adalah suatu bentuk penulisan sejarah dalam lingkup yang terbatas yang meliputi suatu lokalitas tertentu. Sejarah lokal diartikan sebagai studi tentang kehidupan masyarakat atau khususnya komunitas dari suatu lingkungan sekitar (neighborhood) tertentu dalam dinamika perkembangannya terhadap berbagai aspek kehidupan manusia.

Pernyataan kedua di atas tidak jauh berbeda dengan apa yang dikemukakan oleh Carol Kammens (2003) yang menyatakan bahwa "local history is the study of the past events,

Taufik Abdullah. Sejarah Lokal di Indonesia. (Yogyakarta: Gadja Mada University Press, 1985), hlm. 15.

2 I. Gde Widja. Sejarah Lokal Suatu Perspektif dalam Pengajaran Sejarah. (Jakarta: Departemen Pendidikan dan Kebudayaan, 1989), hlm. 13. 
or people or groups, in a given geographic area. The focus of the local history can be the place itself, the people who lived there or events that took place in a particular location". 3 Terjemahannya: "studi tentang peristiwa masa lalu, atau orang atau kelompok, di suatu wilayah geografis tertentu. Fokus sejarah lokal bisa tempat itu sendiri, orang-orang yang tinggal di sana atau peristiwa yang terjadi di lokasi tertentu".

Pengertian di atas secara konseptual dapat membantu kita untuk membedakan sejarah lokal dengan sejarah daerah. Sebuah peristiwa, baik yang sudah terjadi, sedang terjadi, maupun yang akan terjadi tidak dapat dibatasi secara administratif. Setiap peristiwa terjadi dalam konteks dan ruang tertentu yang kadang sulit dibedakan aspek mana yang diharapkan (intended result) dan aspek mana yang tidak diharapkan (unintended result). Dalam kondisi semacam ini diperlukan suatu "imaginasi sejarah".

Dalam penerapan imaginasi sejarah, sejak awal dalam pemilihan tema atau topik yang akan diteliti dalam sejarah lokal dapat dipertanyakan. Salah satu pertanyaannya adalah "apakah suatu peristiwa yang terjadi pada lokal tertentu itu steril, tidak dipengaruhi ataupun mempengaruhi, peristiwa sejarah di tempat lain." Misal, suatu peristiwa sejarah sosial di suatu masyarakat yang biasa mengadakan "selamatan". Biasanya proses selamatan yang diadakan tidak hanya dipengaruhi oleh peristiwa sebelumnya yang terjadi di lokasi tersebut, melainkan juga dipengaruhi oleh peristiwa yang terjadi di lokasi lain. Demikian pula pola kehidupan maupun bangunan rumah masyarakat pedesaan kontemporer. Ada beberapa rumah yang mencolok dengan gaya arsitektur kontemporer. Ternyata rumah tersebut dapat terbangun dengan adanya warga yang menjadi tenaga kerja di luar negeri. ${ }^{4}$

dalam Hariyono. Sejarah Lokal: Mengenal yang Dekat, Memperluas Wawasan. (Sejarah dan Budaya, Tahun Kesebelas, Nomor 2, Desember 2017), hlm. 162. Hariyono. Loc.cit 
Dalam studi kasus tentang area dan tema tertentu, sejarah lokal memberikan wawasan misalnya, bagaimana kehidupan di tempat tertentu di masa lalu yang berevolusi dalam berbagai pengaturan, baik di perkotaan maupun pedesaan Karenanya, penelitian sejarah lokal memungkinkan pandangan sekilas ke dunia yang beragam dan saling berinteraksi yang merupakan dasar dari pengalaman historis. Yang penting untuk diperhatikan, bahwa sejarah lokal bukanlah pengumpulan fakta atau penyajian "bahan sumber" dalam bentuk narasi, melainkan pertanyaan yang ketat dari sumber-sumber yang diperoleh agar dapat memberikan informasi. Mengajukan pertanyaan yang tepat adalah bagian utama bagaimana sejarah lokal dituliskan. Hal ini merupakan kunci yang tepat dalam penggunaan imajinasi historis yang dapat menghidupkan masa lalu, dan membuat studi lokal tentang relevansi batas-batas di luar kota dengan kota atau kabupaten yang merupakan fokus utama. ${ }^{5}$

Sejarah lokal dapat menjadi lapangan studi yang menyenangkan bagi pencari kekayaan makna pada masa lalu. Sejarah lokal berkaitan dengan suatu kompleks atau lingkungan sekitar, seperti kota kecil atau desa, suatu komunitas pertanian atau agrikultur, atau bahkan seluruh kota atau kabupaten. Sejarah lokal mencakup semua sejarah lokalitas tertentu dari mulai ada sampai sekarang, atau mungkin menggarap bagian kecil saja dari waktu ke waktu. Sejarah lokal mencoba menghadirkan sejarah lokalitas secara keseluruhan, yang mempertimbangkan hubungan dari berbagai aspek pengalaman, baik konflik maupun persatuan komunitas karena suatu kepentingan. Sejarah lokal terfokus pada proses pertumbuhan dan perkembangan komunitas. Mungkin juga, sejarah lokal menekankan pada salah satu tema sejarah yang telah berlaku, seperti pada sejarah sosial, sejarah ekonomi, sejarah militer, sejarah kolonial, sejarah politik, atau sejarah intelektual. Sejarah lokal juga dapat

Miftahuddin. Metodologi Penelitian Sejarah Lokal. (Yogyakarta: UNY Press, 2020), hlm. 5 . 
mengangkat tema khusus, misalnya tentang anggota komunitas pertanian yang menjual hasil panen, hubungan antar etnis di wilayah sekitar urban (kota), atau reformasi prosedur pemerintahan di suatu kota kecil.

Sugeng Priyadi ${ }^{6}$ menyebutkan, bahwa studi sejarah lokal memiliki empat corak, yaitu peristiwa khusus, struktur, tematis, dan sejarah umum. Pertama, yang dimaksud peristiwa khusus adalah bahwa corak kajiannya difokuskan pada peristiwa tertentu, atau studi peristiwa khusus. Studi peristiwa khusus adalah peristiwa yang sudah diterima kenyataannya. Kedua, studi struktur dalah memfokuskan persoalan struktur tetapi bukan peristiwa yang dilahirkan dari struktur. Misalnya, persoalan struktur yang bisa diangkat adalah struktur sosial, sistem pelapisan sosial, struktur budaya, struktur birokrasi, dan lainnya.

Ketiga, studi tematis yang dimaksud adalah studi yang mengangkat perkembangan aspek tertentu dan dalam kurun waktu tertentu. Aspek-aspek yang dapat dikaji, misalnya, terkait dengan pendidikan, keintelektualan, ide-ide, mentalitas, perkotaan, pedesaan, perdagangan, dan lain-lain. Keempat, yang dimaksud dengan studi sejarah umum adalah studi yang menguraikan perkembangan lokal tertentu, seperti provinsi, kabupaten, kota, kecamatan, desa atau kelurahan. Studi sejarah umum tentu saja penulisan sejarah lokal yang menyeluruh yang pada praktiknya perlu disokong dengan peristiwa yang khusus, struktur, dan tematis.

Sejalan dengan pandangan ini, maka diperlukan definisi formal dari bidang akademik sejarah lokal yang memperluas batas-batas sejarah lokal untuk memasukkan berbagai narasi sejarah lokal akademik dan non-akademik. Seperti sejarah publik atau sejarah politik, sejarah lokal adalah sebuah konsep. Ini dapat dianggap sebagai kiasan narasi atau genre yang mengasumsikan referensi ke tempat terdekat. Tempat geografis ini bervariasi untuk setiap buku dan setiap

Sugeng Priyadi. Sejarah Lokal: Konsep, Metode dan Tantangannya. (Yogyakarta: Ombak, 2012), hlm. 77-82. 
penulis. Ini bisa berupa wilayah multi-negara, jalan, lingkungan, kota, badan air, atau bagian landskap. Fokus sejarah lokal dapat menjadi tempat itu sendiri, orang-orang yang tinggal di sana atau peristiwa yang terjadi di lokasi tertentu. Studi narasi sejarah lokal juga menyatukan tulisantulisan tentang masa lalu, baik amatir dan akademis.

\section{B. Tantangan Penulisan Sejarah Lokal}

Dalam penulisan sejarah lokal, tahap paling awal penulisan sejarah lokal adalah menemukan sumber-sumber yang dapat dipercaya dan relevan dengan permasalahan yang diajukan, baik sumber tertulis (dokumen/arsip) sezaman, sumber lisan dari orang yang mengalami, maupun sumbersumber lainnya berupa artefak seperti monumen, bangunan fisik, tradisi lisan, dan situs-situs peninggalan masa lalu. Langkah pertama ini disebut "heuristik". Pada tahap ini sejarawan mencari, menemukan, dan mengumpulkan sumber-sumber sejarah sesuai topik penelitian sejarah lokal yang dikaji. Selanjutnya merupakan tahap "kritik sumber" yakni menganalisis secara kritis sumber-sumber sejarah. Tujuan yang hendak dicapai dalam tahap ini adalah untuk dapat menilai sumber-sumber yang relevan dengan masalah yang dikaji dan membandingkan data-data yang diperoleh dari sumber-sumber primer maupun sekunder dan disesuaikan dengan tema atau judul penulisan sejarah lokal. Selanjutnya adalah tahap "interpretasi" yakni sejarawan memberikan tanggapan (analisis) terhadap fakta-fakta sejarah yang didapatkan dari dalam sumber sejarah. Fakta sejarah yang ditemukan tersebut kemudian dihubungkan dengan konsep yang berhubungan dengan permasalahan yang dikaji pada sejarah lokal. Terakhir adalah tahap "historiografi" yaitu memberi keterangan sejarah (eksplanasi) menurut perspektif tertentu. ${ }^{7}$ Jadi, menemukan, mengisahkan, menerangkan

Rizka Fauzan. Penulisan Sejarah Lokal Indonesia (Wacana Magis-Religio hingga Pendekatan Multidimensional). (Prosiding Seminar Nasional Pendidikan FKIB Volume 3 No 1 Tahun 2020, hal. 367-375), hlm. 369. 
adalah rangkaian kerja sejarawan dalam merekonstruksi masa lalu yang menjadi pokok kajiannya.

Tantangan pertama yang dihadapi sejarawan dalam penulisan sejarah lokal adalah menemukan sumber sejarah lokal itu sendiri. Apakah sumber tersebut merupakan sumber asli (Primer), atau sumber turunan (Sekunder). Sumber sejarah tersebut harus bisa dipertanggungjawabkan validitas dan otensitasnya baik secara bentuk maupun isi (konten). Sebagian besar sumber sejarah lokal memiliki karakteristik primodialisme tinggi dari segi bahasa dan dialek, tulisan, dan ragamnya. Tantangan sejarawan selanjutnya adalah kesulitan dalam melakukan kajian terhadap sumber berupa naskah. Sebagian besar naskah sejarah lokal memuat unsur mitos dan legenda lebih dominan dibandingkan narasi sejarahnya. Hal tersebut menyebabkan naskah akan sulit dibedakan antara fakta sejarah dan fiksi. Kemudian tradisi lisan sebagai sumber sejarah juga menjadi tantangan bagi sejarawan dalam mengungkap fakta sejarah. Folklore dan tradisi lisan lebih banyak mengungkapkan fakta mentalitas dibandingkan fakta sejarahnya.

Selain naskah dan tradisi lisan sebagai sumber sejarah lokal, tantangan penulisan sejarah lokal juga adalah merekonstruksi sumber-sumber peninggalan kolonial. Pemanfaatan sumber kolonial ini perlu ditinjau secara kritis oleh sejarawan karena cara pandang bangsa asing terhadap pribumi. Dalam beberapa segi apa yang ditulis orang asing (Belanda) itu tidak tepat atau bahkan bertolak belakang dengan kenyataan yang sesungguhnya terjadi di masyarakat. Namun bagaimanapun, sumber tertulis yang cukup penting ini tidak bisa ditinggalkan oleh penulis sejarah lokal karena kaya informasi. Beberapa sumber Belanda yang penting antara lain laporan kolonial (Koloniaal Verslag, Regeeringsalmanak), lembaran negara (Staatsblad, Besluit, Bijblad), laporan serah jabatan (Memorie van Overgave), dan arsip lainnya yang dihimpun dalam koleksi Algemeen Secretarie atapun Leiden/KITLV. Selain itu, terdapat koran, 
majalah, dan terbitan berkala (Bataviaasch Nieuwsblad, The Indische Mercuur) yang sangat bermanfaat untuk penelitian sejarah lokal. Singkatnya, sumber Belanda yang berupa laporan para pegawai Pemerintah Hindia Belanda, perusahaan swasta, para pedagang, misionaris, dan para pelancong, semuanya memberikan informasi tentang dinamika masyarakat Hindia Belanda selama periode kolonial. Tantangannya, selain harus mengetahui tempat arsip-arsip itu disimpan, sejarawan juga harus mampu memahami isinya karena ditulis dalam bahasa asing (Belanda). ${ }^{8}$

Sejarah lokal sering diwarnai konsep mitos (clouded in myth) dan mendorong sejarawan larut dalam anggapan. Maksudnya, peneliti larut dengan anggapan masyarakat lokal dimana peristiwa tersebut dipersepsikan selama ini. Nilai dan praanggapan kultural masyarakat setempat lebih dijadikan referensi dibanding referensi teoretis dan metodologis yang tersedia. Untuk itu pemahaman tentang metodologi dan teori yang relevan dengan topik yang diteliti menjadi sangat diperlukan dalam penelitian sejarah lokal. Kejadian semacam itu sebaiknya dihindari semaksimal mungkin. Peneliti perlu waspada, biasanya dilakukan dengan otokritik, akan kemungkinan menyelinapnya unsur-unsur ahistoris dari topik sejarah yang diteliti sebagai pertimbangan interpretasi. Eksistensi sejarah sebagai ilmu yang logis dan empiris dapat menjadi acuan selama berlangsungnya penelitian dan atau penulisan sejarahnya. Dalam sejarah lokal yang terkait dengan tujuan wisata, dimensi mitos tersebut biasanya dikemas dalam suatu kisah yang menarik dan tidak jarang dijadikan sebagai salah satu ikon. ${ }^{9}$

Dengan pemahaman sejarah lokal di atas memungkinkan penelitian dan penulisan sejarah tidak hanya bersifat deskriptif, melainkan juga dapat dilakukan secara

Warto. Tantangan Penulisan Sejarah Lokal. (Jurnal sejarah dan budaya, Tahun Kesebelas, Nomor 1, Juni 2017), hlm. 155.

Hariyono. Op.cit., hlm. 163. 
analitis dan reflektif. Penelitian sejarah lokal dengan demikian juga dapat menjadi bagian gerakan "kesadaran diri" sekaligus sarana pengembangan kapasitas belajar bagi peneliti dan pembacanya. Si peneliti perlu membaca sumber-sumber yang relevan dengan topik yang menarik dirinya. Untuk itu sejak dalam pemilihan topik perlu dirumuskan tentang apa yang akan diteliti secara serius dan reflektif. Topik yang dipilih memang ada bukti yang dapat dijadikan pijakan awal terjadi pada suatu area atau lokal tertentu. Dengan sumber informasi yang dimiliki kemudian ditentukan apakah topik tersebut lebih layak untuk makalah, penelitian skripsi, tesis atau disertasi atau untuk pengembangan wisata hingga dasar pemekaran wilayah administratif baru.

\section{Dinamika Penulisan Sejarah Lokal Lubuklinggau}

Penulisan sejarah lokal yang dikhususkan di wilayah Lubuklinggau dari periode masa lampau hingga sekarang dikatakan masih minim. Mengingat keterbatasan sumber referensi berdasarkan kaidah-kaidah ilmiah yang belum dapat menunjang informasi. Pengetahuan tentang sejarah lokal Lubuklinggau lebih banyak berdasarkan hasil penutur tradisi lisan kemudian dimuat dalam tulisan-tulisan pribadi dari tokoh-tokoh lokal. Kemudian informasi sejarah ini sangat beredar luas, sedangkan sumber informasi dikesampingkan oleh penyebar media. Seperti apa yang telah dikemukakan sebelumnya oleh Taufik Abdullah ${ }^{10}$, bahwa kebanyakan penyebar informasi larut dengan anggapan masyarakat lokal dimana peristiwa tersebut dipersepsikan selama ini. Nilai dan praanggapan kultural masyarakat setempat lebih dijadikan referensi dibanding referensi teoretis dan metodologis yang tersedia. Untuk itu pemahaman tentang metodologi dan teori yang relevan dengan topik yang diteliti menjadi sangat diperlukan dalam penelitian sejarah lokal.

10 dalam Hariyono. Op.cit., hlm. 163.

8| SEJAR A H L U B UK L N G G U U 
Dengan kejadian ini, informasi sejarah lokal khususnya mengenai Lubuklinggau yang beredar di media internet dan media sosial perlu dilakukan kajian ulang agar tidak terjadi penyimpangan informasi. Kejadian semacam itu membuat niat para pegiat sejarah lokal Lubuklinggau tergugah untuk menceritakan narasi sejarah yang sebenarnya. Yang paling utama ialah referensi yang menjadi sumber informasi harus jelas dan kredibel. Apakah ada bukti tertulis atau hanya tradisi lisan. Terutama berkaitan dengan perkembangan awal Lubuklinggau pada saat Belanda menanamkan kekuasaannya. Sehingga harus disesuaikan fakta sejarah yang otentik, lalu berdasarkan pada sumber arsip sezaman yang menceritakan sejarah lokal itu sendiri demi meminimalisir berita-berita sejarah yang subjektifitas (terkesan dibuat-buat). Sumber akurat akan mendukung dan menguatkan sejarah itu sendiri mengingat hal ini merupakan kejadian masa lalu yang harus ditampilkan pada khalayak umum.

Dalam rangka penulisan buku ini, penulis telah terlebih dahulu melakukan studi awal untuk menelusuri sumbersumber sejarah lokal di Lubuklinggau, dan Museum Perjuangan Subkoss Garuda Sriwijaya sedikit banyaknya menyimpan beberapa arsip historik sejarah lokal karena gedung museum merupakan artefak sejarah yang ditinggalkan oleh Belanda saat berada di Lubuklinggau. Akan tetapi, ditemukan belum ada hasil penulisan sejarah yang terstruktur sehingga membutuhkan sumber lain di luar Lubuklinggau. Arsip Belanda menjadi andalan penulis sehingga menjadi sumber primer meskipun harus diolah kembali dengan memahami isi naskah untuk menjadi sumber yang kredibel.

Pengetahuan dan wawasan sejarah lokal Lubuklinggau sangat perlu dilakukan kajian dan penelitian yang berkelanjutan di masa mendatang, sehingga apa yang akan penulis paparkan dalam buku ini menjadi sangat penting dan membuka cakrawala sejarah dalam dunia akademisi mengenai Lubuklinggau. Urgensi penelitian lokal yang 
masuk ke ranah akademisi bertujuan agar sejarah Indonesia tidak lagi hanya bersifat Jawa sentris. Oleh karena di dalam dunia pendidikan sejarah di Indonesia secara umum masih sangat terpengaruh dengan penulisan sejarah Jawa sentris sehingga penelitian lokal menjadi sangat penting.

Dalam konteks memahami sejarah nasional, tidak terlepas dengan penulisan sejarah lokal saat ini. Memahami sejarah lokal bukan sebagai sejarah sebuah daerah atau sejarah komunitas tertentu saja, namun bagaimana posisi sejarah lokal merupakan bagian penting dalam historiografi nasional. Sebagai upaya mempertahankan identitas nasional (national identity) dan pembangunan karakter nasional (national character building) penulisan sejarah lokal saat ini menjadi pilar penting dalam memperkuat sikap Nasionalisme dalam menghadapi tantangan disintegrasi bangsa akhir-akhir ini. Terutama penelitian mengenai Lubuklinggau yang memiliki sejarah yang cukup utuh dalam dinamika sejarah lokal. Sehingga hal ini berdampak pada generasi muda yang tidak memahami tentang sejarah kota ini.

\section{Metode Penelitian}

Buku yang merupakan kumpulan artikel ini merupakan hasil penelitian yang cukup panjang dan memerlukan konsep kajian yang lebih mendalam. Agar kajian dalam buku ini menjadi lebih baik penggunaan metode penelitian sangat diperlukan. Kajian yang mengangkat tema Sejarah Lubuklinggau ini menggunakan metode penelitian sejarah denagn langkah-langkahnya, yaitu heuristik, verifikasi, interpretasi dan historiografi.

Pertama, langkah heuristik, langkah pertama ini yaitu dengan mengumpulkan data sejarah, dengan menggali sumber-sumber primer yang tersimpan dalam koleksi Museum Perjuangan Subkoss Garuda Sriwijaya, antara lain catatan-catatan para pejuang kemerdekaan: (1). Catatan Monumen Perjuangan Subkoss Garuda dan Museum Perang Kemerdekaan Subkoss Garuda Sriwijaya; (2). Buku 
Regeeringsalmanak voor Nederlansch-Indie dari tahun 1906 sampai tahun 1942). Buku ini merupakan laporan pemerintah Hindia Belanda yang dikeluarkan setiap tahun dalam segala aspek; (3). Arsip Staatsblad Nederlansch-Indie yang merupakan lembar negara yang dikeluarkan sesuai nomor seri; (4). Buku De Palembangsche Marga En Haar Gronden Waterrechten yang membahas tentang perkembangan marga-marga di Sumatera Selatan; (5). Buku Rapport Den Aanleg Staatsspoorwegen Zuid Sumatera merupakan laporan awal tentang keadaan Sumatera Selatan dalam aspek pembangunan jalur transportasi kereta api; (6). Surat kabar/majalah yang terbit sezaman seperti De Locomotief Eeerste Blad; (7). Boekoe Peringatan dari Staatsspoor en Tramwegen di Hindia Belanda 1875-1925, membahas tentang sejarah pembangunan kereta api di Hindia Belanda termasuk Sumatera Selatan; (8). Spoor- En Tramwegen: 14-Daagsch Tijdschrift Voor Het Spoor- En Tramwegwezen In Nederland En Indiè, membahas tentang ekspedisi pengangkutan di jalur kereta api dari Tebing Tinggi - Muara Saling - Lubuklinggau; (9). DE INDISCHE MERCUUR: Weekblad voor Handel, Landbouw, Nijverheid en Mijnwezen in Nederlandsch Oost- en West-Indië, membahas tentang tentang pembangunan jalur kereta api dari Tebing Tinggi-Muara Saling-Lubuklinggau; Kemudian ditambah dengan sumber-sumber sekunder berupa buku-buku yang membahas tentang Sejarah Sumatera Selatan yang diterbitkan oleh Departemen Pendidikan dan Kebudayaan Propinsi Sumatera Selatan.

Kemudian ditambah dengan sumber sekunder berupa buku, bunga rampai, artikel, catatan-catanan dan karya tulis lainnya yang tersimpan dalam koleksi buku di Museum Perjuangan Subkoss Garuda Sriwijaya dan artikel-artikel online yang berkaitan dengan sejarah Lubuklinggau dari masa kolonial hingga perjuangan kemerdekaan.

Kedua, langkah berikutnya yaitu verifikasi, tahap ini merupakan langkah Kritik terhadap Sumber yang diperolah, yakni menyelidiki apakah jejak itu sejati baik bentuk maupun isinya. Pada tahap ini, penulis menggunakan dua tahap kritik 